\title{
Estimating The Interregional Incidence Of Regional Business Taxes
}

\author{
Richard D. Gustely*
}

\section{Introduction}

The desirability of integrating an analysis of the interregional incidence of the state and local government sector into regional models has long been recognized. ${ }^{1}$ From a public policy standpoint, the understanding of the extent of interstate shifting of state and local taxes is particularly important. With respect to state-local development policy, for example, it is necessary that decision makers be aware of the extent to which alternative taxes affect the level of output and employment within the state. Similarly, any national policy (e.g., revenue sharing) aimed at alleviating the fiscal imbalance among states should consider the extent of interstate shifting of tax burdens.

Given the importance of these questions, it is somewhat surprising that such issues seldom enter the policy debate. One possible explanation for this fact is that the method used in previous studies might be brought into question. Heretofore, estimates of the interregional incidence of regional business taxes have been obtained by making certain assumptions concerning the extent of forward and backward shifting of each tax and by allocating the burdens across regions accordingly. ${ }^{2}$ The difficulty with this approach is that there is little theoretical agreement over the extent of forward versus backward shifting of business taxes. With respect to the property tax, one school of thought dating back to Alfred Marshall [14] holds that the tax is equivalent to an excise tax and is shifted to consumers. Another, apparently also beginning with Alfred Marshall [13], suggests that the tax is borne by owners of immobile factors of production (notably land). Still a third school of thought, dating back to Harry Brown [2], contends the tax is equivalent to a profits tax and is thus borne by the owners of capital. Similar disagreement is evident with respect to the incidence of the business income tax. The traditional approach is to argue that, since the tax is on net profits, it cannot be shifted forward when the industry being taxed is less than perfectly competive.

\footnotetext{
*The author is Assistant Professor of Economics at The University of Tennessee/Knoxville. The author wishes to express his appreciation to Professors Roy Bahl and Jesse Burkhead of Syracuse University who initially suggested the importance of the topic considered herein and whose comments on earlier drafts were quite helpful. The author is also indebted to Robert Dinkelmeyer for his assistance in generating the simulated distributions included here.
} 
Some of this disagreement concerning incidence can be traced to the reliance of early writers on partial rather than general equilibrium analysis. The presentation of the general equilibrium models of Harberger [8], Mieszkowski [17] and McLure [15] pointed out these problems. Further disagreement has resulted from a failure to distinguish between the global effects of the system taxes and the partial effects of tax differentials. Mieszkowski [19] has discussed the implications of this distinction for the property tax. Still, while the theoretical issues concerning the incidence of the tax are in clearer focus now than before the 1960 s, empirical questions relating to the actual patterns of incidence of business taxes in the United States remain unresolved. ${ }^{3}$ Foremost among them is the extent to which the incidence of specific taxes varies significantly across regions. ${ }^{4}$

Given this disagreement on both theoretical and empirical grounds over past studies, this paper will describe a method which can be employed to make region-specific estimates of tax incidence not based upon assumptions concerning forward and backward shifting of tax burdens. More specifically, the focus of this paper is on demonstrating how the incidence of two business taxes-a business property tax and a business income tax-might be estimated for New York State using a general equilibrium model. Simulated distributions of the interregional effects of the two taxes on prices, employment, output and income were obtained based upon a range of likely parameter values. The next section of this paper includes a brief description of the model and its assumptions. This is followed by a discussion of the methodology employed in estimating the independent variables. In the final sections of the paper the results are analyzed and their implications assessed.

\section{A Model of Interregional Tax Incidence}

In order to take account of the interregional relationship which are of prime importance in determining the extent of interstate tax shifting, it is helpful to employ a general equilibrium model. The general equilibrium model used here was first employed by Harberger [8] to analyze the corporate income tax, and later by McLure [15] to analyze the business property and income taxes. This model has the virtue of employing relatively few variables while still maintaining its general equilibrium nature. This characteristic is particularly helpful when the model is used for estimating purposes, as in this study.

The model is based upon four assumptions. ${ }^{5}$ First, each of two regions produces a single product governed by a linearly homogenous production function, with two factors of production-capital and labor. Second, the total amount of capital and labor are in fixed supply and fully employed. Third, capital is mobile between regions while labor is immobile. ${ }^{6}$ Finally, factor groups in each region have the same price elasticity of demand for production in the taxed region. 
Given these assumptions, the model is comprised of six equations:

$$
\begin{aligned}
& \frac{\partial \mathrm{X}}{\mathrm{X}}=-\mathrm{E}\left(\partial \mathrm{P}_{\mathrm{X}}\right) \\
& \frac{\partial \mathrm{X}}{\mathrm{X}}=\mathrm{f}_{\mathrm{L}} \frac{\partial \mathrm{L}_{\mathrm{X}}}{\mathrm{L}_{\mathrm{X}}}+\mathrm{f}_{\mathrm{K}} \frac{\partial \mathrm{K}_{\mathrm{X}}}{\mathrm{K}_{\mathrm{X}}} \\
& \partial \mathrm{P}_{\mathrm{X}}=\mathrm{f}_{\mathrm{L}}{ }^{\partial \mathrm{P}_{\mathrm{LX}}}+\mathrm{f}_{\mathrm{K}}\left(\partial \mathrm{P}_{\mathrm{K}}+\partial \mathrm{T}_{\mathrm{KX}}\right)+\partial \mathrm{T}_{\mathrm{X}} \\
& \partial \mathrm{P}_{\mathrm{Y}}=\mathrm{g}_{\mathrm{L}}{ }^{\partial \mathrm{P}_{\mathrm{LY}}}+\mathrm{g}_{\mathrm{K}}\left(\partial \mathrm{P}_{\mathrm{K}}\right) \\
& \frac{\partial \mathrm{K}_{\mathrm{X}}}{\mathrm{K}_{\mathrm{X}}}-\frac{\partial \mathrm{L}_{\mathrm{X}}}{\mathrm{L}_{\mathrm{X}}}=-\mathrm{S}_{\mathrm{X}}\left(\partial \mathrm{P}_{\mathrm{K}}+\partial \mathrm{T}_{\mathrm{KX}}\right) \\
& \frac{\partial \mathrm{K}_{\mathrm{Y}}}{\mathrm{K}_{\mathrm{Y}}}-\frac{\partial \mathrm{L}_{\mathrm{Y}}}{\mathrm{L}_{\mathrm{Y}}}=-\mathrm{S}_{\mathrm{Y}}\left(\partial \mathrm{P}_{\mathrm{K}}\right)
\end{aligned}
$$

where:

$\mathrm{X}=$ aggregate state product for the taxed region

$\mathrm{P}=$ price of factor or product

$\mathrm{K}=$ units of capital

$\mathrm{L}=$ units of labor

$\mathrm{S}=$ elasticity of substition

$\mathrm{E}=$ price elasticity of demand

${ }^{\mathrm{f}} \mathrm{L}$ and $\mathrm{f}_{\mathrm{K}}=$ share of labor and capital in production in the taxed region

$\mathrm{g}_{\mathrm{L}}$ and $\mathrm{g}_{\mathrm{K}}=$ share of labor and capital in production in the nontaxed region

subscript $\mathrm{X}$ or $\mathrm{Y}=$ region referred to

subscript $\mathrm{K}$ or $\mathrm{L}=$ factor referred to

$\mathrm{T}=$ tax per unit

Equations (1) and (2) describe the demand for output and the production function for the taxed region (X). ${ }^{7}$ Equations (3) and (4) indicate the relationship between factor and product prices in the taxed region $(\mathrm{X})$ and the nontaxed region $(\mathrm{Y})$. In equations (5) and (6), the extent of factor substitution in each region is described. Further, it should be noted, as shown in equations (3) and (5), that the tax on income or production $\left(\mathrm{T}_{\mathrm{X}}\right)$ directly affects only the price of the product in the taxed state $\left(\mathrm{P}_{\mathrm{X}}\right)$, while the business property $\operatorname{tax}\left(\mathrm{T}_{\mathrm{KX}}\right)$ directly affects the relative amounts of capital and labor also. ${ }^{8}$ 
The solutions of this set of equations for the key price variables, capital, labor in New Yurk, labor in the rest of the U.S. and New York production, $\left(\partial \mathrm{P}_{\mathrm{K}}, \partial_{\mathrm{LX}}, \partial \mathrm{P}_{\mathrm{LY}}\right.$, and $\partial \mathrm{P}_{\mathrm{X}}$, respectively) yield the following relationships which describe the effects of each tax:

$$
\begin{aligned}
& \text { Property Tax }\left(\mathrm{T}_{\mathrm{KX}}\right) \quad \underline{\text { Income Tax }\left(\mathrm{T}_{\mathrm{X}}\right)}
\end{aligned}
$$

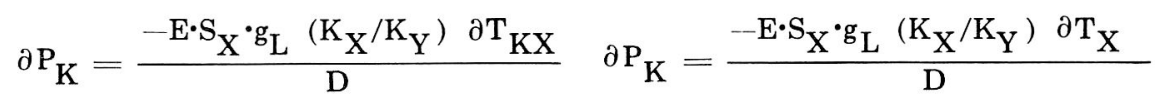

$$
\begin{aligned}
& \partial \mathrm{P}_{\mathrm{LX}}=\frac{{ }_{\mathrm{f}_{\mathrm{K}}} \cdot \mathrm{S}_{\mathrm{Y}}\left(\mathrm{S}_{\mathrm{X}}-\mathrm{E}\right) \partial \mathrm{T}_{\mathrm{KX}}}{\mathrm{D}} \quad \partial \mathrm{P}_{\mathrm{LX}}=\frac{-\mathrm{E}\left(\mathrm{S}_{\mathrm{Y}}+\mathrm{g}_{\mathrm{L}} \mathrm{S}_{\mathrm{X}}\left(\mathrm{K}_{\mathrm{X}} / \mathrm{K}_{\mathrm{Y}}\right) \partial \mathrm{T}_{\mathrm{X}}\right.}{\mathrm{D}} \\
& \partial \mathrm{P}_{\mathrm{LY}}=\frac{\mathrm{E} \cdot \mathrm{S}_{\mathrm{X}} \cdot \mathrm{g}_{\mathrm{K}}\left(\mathrm{K}_{\mathrm{X}} / \mathrm{K}_{\mathrm{Y}}\right) \partial \mathrm{T}_{\mathrm{KX}}}{\mathrm{D}} \quad \partial \mathrm{P}_{\mathrm{LY}}=\frac{\mathrm{ES}_{\mathrm{X}} \mathrm{g}_{\mathrm{K}}\left(\mathrm{K}_{\mathrm{X}} / \mathrm{K}_{Y}\right) \partial \mathrm{T}_{\mathrm{X}}}{\mathrm{D}}
\end{aligned}
$$

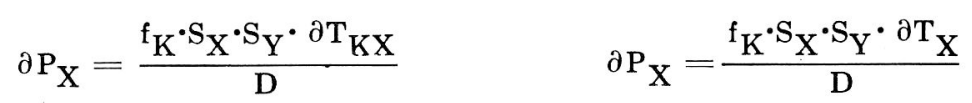

where:

$\mathrm{D}=\mathrm{S}_{\mathrm{Y}}\left(\mathrm{E} \cdot \mathrm{f}_{\mathrm{L}}+\mathrm{S}_{\mathrm{X}}{ }^{\cdot \mathrm{f}_{\mathrm{K}}}\right)+\mathrm{E} \cdot \mathrm{S}_{\mathrm{X}}{ }^{\cdot \mathrm{g}_{\mathrm{L}}} \cdot \mathrm{K}_{\mathrm{X}} / \mathrm{K}_{\mathrm{Y}}$

As can be seen from these solutions, the basic difference between these two taxes is the effect of each on labor prices in the taxed state. For the property tax, the increased price of capital resulting from the tax produces both a factor substitution and an output effect, whereas the tax on production (income) produces only an output effect.

Based upon these solutions to the general equilibrium model, it is possible to estimate the interregional effects of the two taxes under consideration. The basic approach employed here was to obtain estimates of elasticities of demand $(E)$ and substitution $\left(S_{X}\right.$ and $\left.S_{Y}\right)$, relative factor shares $\left(\mathrm{f}_{\mathrm{K}}, \mathrm{f}_{\mathrm{L}}, \mathrm{g}_{\mathrm{K}}\right.$ and $\mathrm{g}_{\mathrm{L}}$ ) and the relative amounts of capital employed in each region $\left(\mathrm{K}_{\mathrm{X}} / \mathrm{K}_{\mathrm{Y}}\right)$. The method used for estimating these parameters is described in the next section. 


\section{Operationalizing the General Equilibrium Model}

Because of the difficulty of measuring the above set of independent variables, simulation analysis is particularly well-adapted to the estimation of the model. Therefore, the method employed here involved first the assignment of ranges to each of the independent variables, and then the simulation of distributions for each of these six key variables, $\partial \mathrm{P}_{\mathrm{K}}, \partial \mathrm{P}_{\mathrm{LX}}, \partial \mathrm{P}_{\mathrm{LY}}, \partial \mathrm{K}_{\mathrm{X}}, \partial \mathrm{P}_{\mathrm{X}}$, and $\partial \mathrm{X} .{ }^{9}$ In the paragraphs which follow the method used in determining the ranges of each of these independent variables is explained. In general, a single estimate was obtained by applying the results of past studies to the New York case. Then ranges were chosen based upon a priori judgments concerning the possible bias of this estimate.

The price elasticity of demand for New York State production (E) was estimated by weighting estimates of price elasticities obtained by Houthakker [10] for various consumer goods by the value added in the manufacture of that product in New York for 1967. However, the value obtained by this method (.75) most certainly is underestimated because of the well recognized fact that the elasticity of demand for a general category of products is generally lower than the elasticity of a subset of those products. To take account of this fact, the range for the price elasticity ( 0.75 to 1.25 ) was chosen.

The estimates for the elasticity of factor substitution $\left(\mathrm{S}_{X}\right.$ for New York State and $\mathrm{S}_{\mathrm{Y}}$ for the rest of the U.S.) were based upon calculations by Solow [27]. Initially, Solow's estimates for manufacturing were weighted by respective amounts of value added in each industry, for New York and similarly for the rest of the U.S. Roughly identical estimates (.90) were obtained by this method for each region. However, these estimates are almost certainly over-stated due to the difficulty of factor substitutability in the nonmanufacturing production process. The range of the elasticity of factor substitution for each region $(0.45$ to 0.90 ) was selected with this bias in mind.

The determination of the relative factor shares of capital and labor in each region $\left(\mathrm{f}_{\mathrm{K}}\right.$ and $\mathrm{f}_{\mathrm{L}}$ in New York and $\mathrm{g}_{\mathrm{K}}$ and $\mathrm{g}_{\mathrm{L}}$ in the rest of the U.S.) also was based upon Solow's estimates of these shares for manufacturing industries. As above, Solow's estimates were weighted by the value added in each industry for New York State and the U.S. The values obtained by this method were again roughly identical for the two regions ( 0.47 for capital's share and 0.53 for labor's share). However, it is generally recognized that nonmanufacturing industries are more labor-intensive than are manufacturing industries. Accordingly, the range for relative shares of capital in each region (0.23 to 0.47) was chosen to reflect this substantial labor input in nonmanufacturing industries. 
The New York gross state product (X) was estimated by assuming that the same relationship of national personal income to gross national product existed between state personal income and gross state product. The estimate for New York in 1967 was $\$ 87.1$ billion, while the gross product for the rest of the U.S. was $\$ 702.6$ billion. This information, together with estimates of relative factor shares, makes determination of factor rewards possible. In this fashion, labor's reward in New York ranged from $\$ 47.0$ billion to $\$ 67.1$ billion, while in the rest of the U.S. it ranged between $\$ 161.6$ billion and $\$ 330.2$ billion. The reward for capital was calculated as a residual.

In order to determine the amount of tax that is shifted out of New York, it is also necessary to estimate both the share of all capital owned by residents of New York and the fraction of New York production exported. In regard to the first variable, based upon the share of U.S. income, New York state residents might be assumed to own roughly 10 percent of U.S. capital. However, due to their higher than average per capita incomes, New York residents probably own a larger share of U.S. capital than implied by their share of total income. The range for this variable (.10 to .20) was chosen to take account of this fact.

The determination of the fraction of New York production exported was estimated by classifying industries as local or export-oriented. Lichtenberg [12] made these estimates for each industry based upon the characteristics of its product. The gross output of Lichtenberg's locally oriented industries was first determined, and then substracted from total output to determine the amount of the New York state product exported. The estimate obtained in this fashion ( 25 percent exported) is probably understated because of the existence in New York state of service industries (classified by Lichtenberg as local) which maintain central offices in New York but export at least a portion of their production. On the other hand, it is possible that some industries which export goods from a given local area, might sell some of them to residents in other localities in the state, causing the estimate based upon Lichtenberg's determination to be somewhat overstated. The range for this variable $(.20$ to .40$)$ was selected to reflect those possibilities.

\section{The Simulated Incidence of Two Business Taxes}

Table 1 presents a summary of the distributions of the simulated price and quantity effects of a one percent general business property tax for New York, compared with an equal yield (0.35 percent) New York business income (production) tax for 1967. Several important conclusions are evident from these data. First, the general effects of the taxes are quite similar. In each case, the price of capital and labor in New York is less, while the price of New York production and labor in the rest of the U.S. is greater than before the tax. Further, both the amount of capital and the total production in New York decrease with the imposition of either of the taxes. In addition, with the exception of 
TABLE 1

Simulated Effects of New York State Business Taxes*

On Factor and Product Prices and Quantities: 1967

(Percentages and Dollars)

\begin{tabular}{|c|c|c|c|c|c|c|c|c|}
\hline \multirow{2}{*}{$\begin{array}{c}\text { Variable } \\
\text { Price Effects }\end{array}$} & \multicolumn{4}{|c|}{ Property Tax } & \multicolumn{4}{|c|}{ Income Tax } \\
\hline & Mean & $\begin{array}{l}\text { Standard } \\
\text { Deviation }\end{array}$ & High & $\begin{array}{l}\text { Range } \\
\\
\text { Low }\end{array}$ & Mean & $\begin{array}{l}\text { Standard } \\
\text { Deviation }\end{array}$ & High & $\begin{array}{l}\text { Range } \\
\text { Low }\end{array}$ \\
\hline $\begin{array}{l}\text { Price of Capital } \\
\partial \mathrm{P}\end{array}$ & -0.088 & 0.036 & -0.027 & -0.222 & -0.030 & 0.012 & 0.009 & -0.076 \\
\hline $\begin{array}{l}\text { Price of Labor-NYS } \\
\partial \mathrm{P}_{\text {LX }}\end{array}$ & -0.111 & 0.070 & 0.058 & -0.329 & -0.383 & 0.024 & -0.458 & -0.325 \\
\hline $\begin{array}{l}\text { Price of Labor-U.S. } \\
\quad \partial \mathrm{P}_{L Y}\end{array}$ & 0.046 & 0.014 & 0.088 & 0.021 & 0.016 & 0.005 & 0.030 & 0.007 \\
\hline $\begin{array}{l}\text { Price of Product-NYS } \\
\qquad \mathrm{P}_{\mathrm{X}}\end{array}$ & 0.240 & 0.064 & 0.400 & 0.149 & 0.083 & 0.022 & 0.138 & 0.042 \\
\hline \multicolumn{9}{|l|}{ Quantity Effects } \\
\hline $\begin{array}{l}\text { Quantity of Capital-NYS } \\
\text { dKX (millions of } \\
\text { dollars) }\end{array}$ & -304.03 & 67.03 & -188.44 & -459.51 & -206.99 & 42.76 & -134.62 & -291.43 \\
\hline $\begin{array}{l}\text { Quantity of Capital-NYS } \\
\partial \mathrm{K}_{\mathrm{X}} \text { (percent) }\end{array}$ & -1.00 & 0.079 & -0.814 & -1.190 & -0.681 & 0.029 & -0.615 & -0.749 \\
\hline $\begin{array}{l}\text { Quantity of Production-NYS } \\
\text { (millions of dollars) }\end{array}$ & -299.00 & 66.69 & -186.39 & -448.80 & -203.57 & 42.59 & -132.47 & -284.64 \\
\hline $\begin{array}{l}\text { Quantity of Production-NYS } \\
\partial X \text { (percent) }\end{array}$ & -0.343 & 0.077 & -0.214 & -0.515 & -0.234 & 0.049 & -0.152 & -0.327 \\
\hline
\end{tabular}


the change in the price of labor in New York, the effects of the business property tax are greater on prices and quantities than those of the business income tax. The reason for this exception is that the increased demand for labor in New York, which results from the property taxinduced substitution of labor for capital there, limits the decrease in wages produced by the tax-induced output effect.

The relative importance of the opposing pressures on prices as indicated by these price effects is also interesting to point out. As might be expected, the tax is apparently partially capitalized in the price of capital, and partially passed forward to consumers in the form of higher product prices. In terms of the price of labor, the rising relative price of New York production caused consumers to increase purchases of outof-state products, resulting in upward pressure on out-of-state wages. As for New York state laborers, dwindling purchases of New York state products generally appears to have produced downward pressure on wages in the state, causing this factor group to share in the burden of the tax.

The incidence of these taxes also can be shown by the effects of the taxes on the incomes of the various factor groups in each region. Adopting the terminology suggested by Musgrave [21] and McLure [15], it is helpful to divide the effects of a tax into those arising on the sources side and those arising on the uses side of income. Focusing on price effects on the uses side, real income can be changed when a tax changes the price of a purchased product. On the sources side, real income can be changed when the price or quantity of either capital or labor is affected by the tax. In mathematical terms: ${ }^{10}$

$$
\begin{aligned}
& \partial \mathrm{R}^{\mathrm{S}}=\partial \mathrm{P}_{\mathrm{L}} \cdot \mathrm{L}+\partial \mathrm{P}_{\mathrm{K}} \cdot \mathrm{K} \\
& \partial \mathrm{R}^{\mathrm{U}}=\partial \mathrm{P}_{\mathrm{X}} \cdot \mathrm{X}
\end{aligned}
$$

where:

$$
\begin{aligned}
& \mathrm{R}=\text { real income } \\
& \text { superscripts } \mathrm{S} \text { or } \mathrm{U} \text {--sources or uses of income }
\end{aligned}
$$

As above, this terminology can be used to apply either to New York State (X) or to the rest of the U.S. (Y) by the simple addition of a subscript.

Further, the amount of the tax that is shifted out of New York State can be determined by comparing the changes in total real income between the two areas. Specifically, for these purposes, the fraction of the tax shifted to out-of-state residents may be defined (in terms of the definition of Musgrave [21]) as:

$$
\frac{\partial R_{Y}}{\partial R_{X}+\partial R_{Y}}
$$


Table 2 presents a summary of simulated distribution of the effects of the taxes on the sources and uses of income for New York and the rest of the U.S. As might be expected, New York residents bear a relatively larger share of the burden of both taxes in terms of the uses and sources of income. In fact, New York's burden is between four and five times that for the rest of the U.S. for the property tax, and much greater for the income tax. However, when examining the sources side of income closely in each area, some interesting contrasts are evident. In New York, both labor and capital are hurt by the taxes, with labor bearing a relatively greater burden. In the rest of the U.S., on the other hand, labor benefits while capital suffers as a result of the tax. This differential effect on factor incomes arises from the immobility of labor, which results in a separate price effect in each area. ${ }^{11}$

Several differences in the burden of the two taxes are also evident from the results of Table 2. First, in New York, the burden of the property tax is greater on the uses side of income, while the burden for the income tax is greater on the sources side. Second, the total effect of the property tax on labor and capital incomes for the rest of the U.S. is substantially greater than that for the income tax, although the net effect on the sources side of income is not much different for the two taxes. Finally, the extent of shifting of the two taxes in substantially different. While an average of about 18 percent of the burden of the property tax is shifted out-of-state, only about 6 percent of the burden of the business income tax is so shifted.

\section{Summary, Conclusions and Implications}

The purpose of this paper has been to demonstrate how a general equilibrium model might be used to estimate the interregional incidence of statewide taxes. The simulated incidence of two New York general business taxes-a property tax and an income tax-was estimated and compared for 1967. The empirical estimates reported above are summarized in Table 3. ${ }^{12}$ These results raise questions both about the assumptions of forward and backward shifting and the estimates of the extent of interregional shifting obtained from previous studies.

First, with respect to assumptions regarding forward or backward shifting, the property tax results indicate that about 70 percent of the tax burden is borne on the uses side of income (forward shifted), while only 30 percent is borne on the sources side for the entire U.S. Further, when the sources side is disaggregated into labor and capital incomes, the results for the U.S. as a whole imply no backward shifting of the burden. In fact, labor in the aggregate benefits from the tax (about -48 percent) while capital bears the largest fraction of the tax burden (about 79 percent). Although these results concerning forward shifting are similar to those obtained by Mieszkowski [19] and Netzer [24], they differ substantially from the assumption of 100 percent forward shifting employed in the studies of McLure [16] and Phares [26]. 
TABLE 2

Simulated Effects of State Business Taxes* on Sources and Uses of Income: 1967

(Percentages and Millions of Dollars)

\begin{tabular}{|c|c|c|c|c|c|c|c|c|}
\hline Variable & \multicolumn{4}{|c|}{ Property Tax } & \multicolumn{4}{|c|}{ Income Tax } \\
\hline New York State & Mean & $\begin{array}{l}\text { Standard } \\
\text { Deviation }\end{array}$ & High & Low & Mean & $\begin{array}{l}\text { Standard } \\
\text { Deviation }\end{array}$ & $\begin{array}{ll} & \\
\text { High } & \end{array}$ & Low \\
\hline $\begin{array}{l}\text { Real Income-Labor } \\
\partial \mathrm{R}_{\mathrm{L}}^{\mathrm{L}} \text { (millions of } \\
\text { dollars) }\end{array}$ & -61.75 & 36.67 & 32.33 & -157.80 & -216.72 & 22.13 & -165.56 & -259.50 \\
\hline $\begin{array}{l}\text { Real Income-Capital } \\
\partial \mathrm{R}_{\mathbf{K}}^{\mathrm{S}} \text { (millions of } \\
\text { dollars) }\end{array}$ & -35.40 & 13.26 & -14.38 & -81.50 & -12.20 & 4.57 & $-\quad 4.95$ & -28.08 \\
\hline $\begin{array}{l}\text { Real Income-Sources } \\
\partial \mathrm{R}^{\mathrm{S}} \text { (millions of } \\
\text { dollars) }\end{array}$ & -97.15 & 38.34 & -10.05 & -215.08 & -228.92 & 20.17 & -175.75 & -265.32 \\
\hline $\begin{array}{l}\text { Real Income-Uses } \\
\partial \mathrm{R}^{\mathrm{U}} \text { (millions of } \\
\text { dollars) }\end{array}$ & -145.34 & 41.81 & -69.31 & -265.18 & -50.13 & 14.42 & -23.90 & -91.47 \\
\hline $\begin{array}{l}\text { Real Income } \\
\partial \mathrm{R} \text { (millions of } \\
\text { dollars) }\end{array}$ & -242.49 & 45.35 & -147.99 & -336.01 & -279.04 & 8.29 & -256.73 & -297.15 \\
\hline $\begin{array}{l}\text { Real Income } \\
\qquad \partial R_{X} / R_{X} \text { (percent) }\end{array}$ & -.154 & .034 & -.088 & -.226 & -.176 & .012 & -.148 & -.206 \\
\hline
\end{tabular}


TABLE 2 -(Continued)

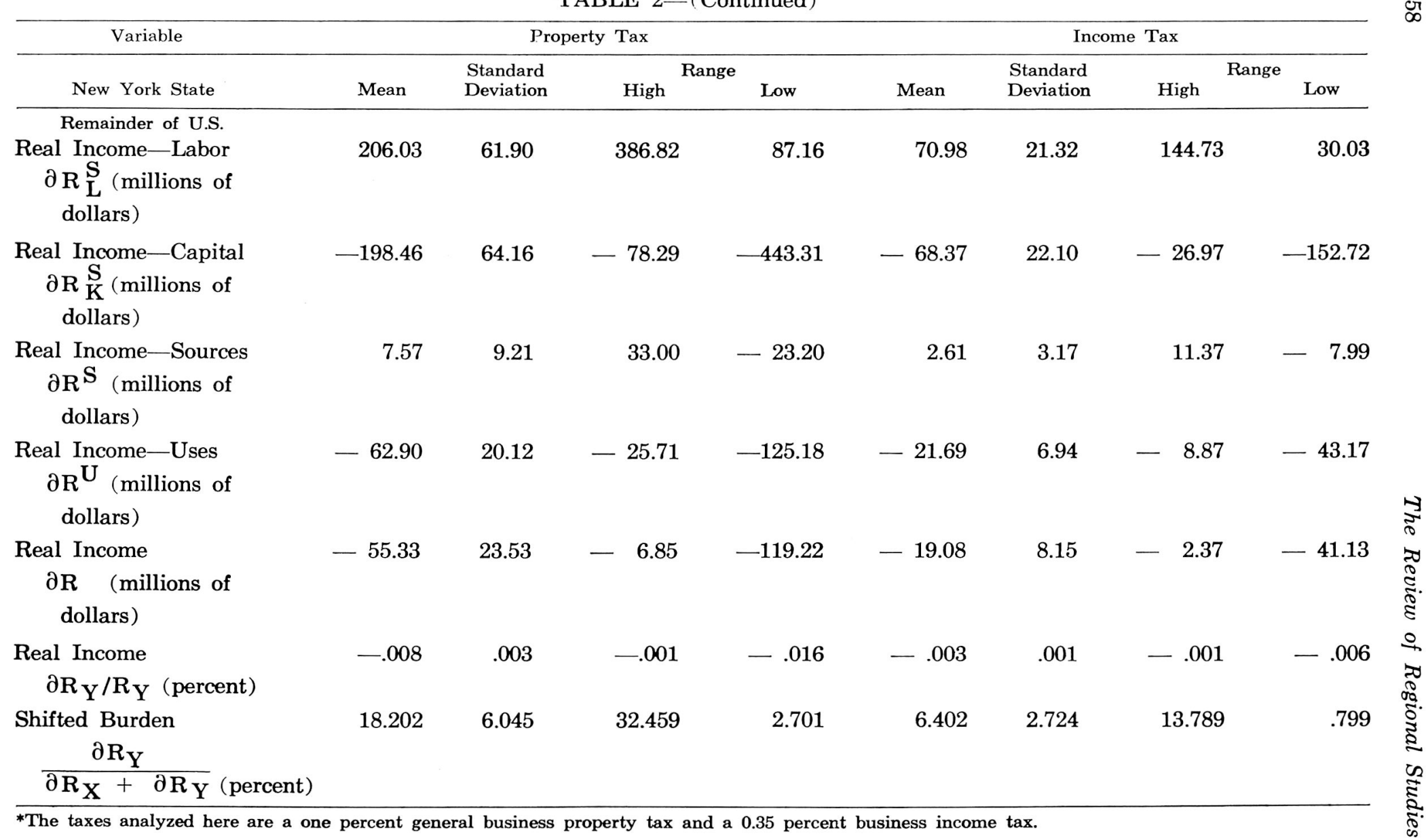


TABLE 3

Summary of the Incidence of New York State General Business Taxes:* Distribution of the Change in Real Income (Percentages and Millions of Dollars)

\begin{tabular}{|c|c|c|c|c|c|c|}
\hline \multirow[b]{2}{*}{ Property Tax } & \multicolumn{2}{|c|}{ New York State } & \multicolumn{2}{|c|}{ Rest of U.S. } & \multicolumn{2}{|c|}{ U.S. Total } \\
\hline & $\begin{array}{l}\text { Change } \\
\text { in Real } \\
\text { Income }\end{array}$ & $\begin{array}{c}\text { Percent } \\
\text { of Total } \\
\text { Burden }\end{array}$ & $\begin{array}{l}\text { Change } \\
\text { in Real } \\
\text { Income }\end{array}$ & $\begin{array}{c}\text { Percent } \\
\text { of Total } \\
\text { Burden }\end{array}$ & $\begin{array}{l}\text { Change } \\
\text { in Real } \\
\text { Income }\end{array}$ & $\begin{array}{c}\text { Percent } \\
\text { of Total } \\
\text { Burden }\end{array}$ \\
\hline $\begin{array}{l}\text { Uses of } \\
\text { Income }\end{array}$ & $\$-145.54$ & 60.0 & $\$-62.90$ & 113.7 & $\$-208.44$ & 69.9 \\
\hline $\begin{array}{l}\text { Sources of } \\
\text { Income }\end{array}$ & -97.15 & 40.0 & 7.57 & -13.7 & -89.58 & 30.1 \\
\hline $\begin{array}{l}\text { TOTAL } \\
\text { INCOME }\end{array}$ & $\$-242.69$ & 100.0 & $\$-55.33$ & 100.0 & $\$-298.02$ & 100.0 \\
\hline $\begin{array}{l}\text { Capital } \\
\text { Income } \\
\text { Labor }\end{array}$ & $\$-35.40$ & 14.6 & $\$-198.46$ & 358.7 & $\$-233.86$ & 78.5 \\
\hline $\begin{array}{l}\text { Income } \\
\text { Consumer }\end{array}$ & -61.75 & 25.4 & 206.03 & -372.4 & 144.28 & -48.4 \\
\hline Income & -145.54 & 60.0 & -62.90 & 113.7 & -208.44 & 69.9 \\
\hline $\begin{array}{l}\text { TOTAL } \\
\text { INCOME }\end{array}$ & $\$ 242.69$ & 100.0 & $\$-55.33$ & 100.0 & $\$ \quad 298.02$ & 100.0 \\
\hline Income Tax & & & & & & \\
\hline $\begin{array}{l}\text { Uses of } \\
\text { Income }\end{array}$ & $\$-50.13$ & 18.0 & $\$-21.69$ & 113.7 & $\$-71.82$ & 24.1 \\
\hline Income & -228.92 & 82.0 & 2.61 & -13.7 & -226.31 & 75.9 \\
\hline $\begin{array}{l}\text { TOTAL } \\
\text { INCOME }\end{array}$ & $\$-279.06$ & 100.0 & $\$-19.08$ & 100.0 & $\$-298.13$ & 100.0 \\
\hline $\begin{array}{l}\text { Capital } \\
\text { Income } \\
\text { Labor }\end{array}$ & $\$-12.20$ & 4.4 & $\$-68.37$ & 358.3 & $\$-80.57$ & -27.0 \\
\hline $\begin{array}{c}\text { Income } \\
\text { Consumer }\end{array}$ & -216.72 & 77.6 & 70.98 & -372.0 & -145.74 & -48.9 \\
\hline Income & -50.13 & 18.0 & -21.69 & $\underline{113.7}$ & -71.82 & -24.1 \\
\hline $\begin{array}{l}\text { TOTAL } \\
\text { INCOME }\end{array}$ & $\$-279.05$ & 100.0 & $\$-19.08$ & 100.0 & $\$-298.13$ & 100.0 \\
\hline
\end{tabular}

*The taxes analyzed here are a one percent general business property tax and a 0.35 percent business income tax.

In contrast to the case for the property tax, the results indicate that only about 24 percent of the business income tax is borne on the uses side of income (forward shifted) with 76 percent borne on the sources side. Further, when the sources side of income is disaggregated, the results indicate substantial backward shifting of the tax. Specifically, capital bears only 27 percent of the burden while labor bears about 49 percent. These results are also quite different from the assumptions used in other studies. For example, McLure [16] assumes 100 percent of the 
tax is borne by capital while Phares [26] assumes 50 percent is borne by consumers (forward shifted) and 50 percent is borne by capital.

The empirical results also suggest the existence of wide variability in the effects of the taxes between regions. ${ }^{13}$ For example, while the burden of the property tax in New York state is divided roughly 60 percent for uses and 40 percent for sources of income, the result for the rest of the U.S. is much different (113.3 percent for uses and - 13.3 percent for sources of income). Similarly, while only about 18 percent of the burden of the business income tax is borne on the uses side of income in New York state, 113 percent of the burden in the rest of the U.S. is borne on the uses side. For both taxes, these results cast serious doubt on the validity of applying a standard set of shifting assumptions for each tax in all regions.

Finally, it should be noted that estimates of the extent of interregional shifting of the taxes derived here differ somewhat from those obtained by McLure [16] in the only other comparable study of New York State. Specifically, McLure estimated that about 10 percent of the business property tax and 50 percent of the corporate income tax in New York were exported, while the results of this study suggest that about 18 percent of the business property tax and 6 percent of the corporate income tax were exported. However, because of the questions raised above concerning the assumptions with respect to forward vs. backward shifting employed by McLure, these differences are not particularly surprising.

At the outset of this study, the need for obtaining estimates of interregional tax incidence for the formulation of regional economic policy was discussed. While previous studies have been useful in providing information to policy makers concerning aggregate interregional tax incidence, their application has been hampered by a failure to employ regionspecific estimates of the incidence of specific taxes. The method described above provides a method of estimating the incidence of specific taxes on a region-by-region basis. It is likely that its application to other taxes and regions can provide insight which, when used in conjunction with the results of other studies, could make more informed public policy decisions possible.

\section{FOOTNOTES}

1See Burkhead [5], Netzer [23] and Perloff and Levin [25].

2 Among the studies employing this approach are O. H. Brownlee [3], R. Musgrave and D. Daicoff [22], C. McLure [16] and D. Phares [26].

3See P. Mieszkowski [18], D. Netzer [24], H. Aaron [1] and R. Musgrave [20].

${ }_{4}^{4}$ See D. Netzer [24].

5 For the sake of brevity, only the essential aspects of the McLure model will be discussed here. For a more complete discussion of the model and its assumptions, see McLure [15].
6The assumption of immobile labor and mobile capital is intended to be an approximation of reality. While it is true that in the long run labor is not perfectly immobile, the assumption is made here to distinguish this factor from capital, which is certainly more mobile in the long run.

${ }^{7}$ While the model is formulated in terms of one taxed region (here New York State) and another with no tax (the rest of the U.S.), a similar interpretation of the results might be obtained if it were assumed that a tax differential exists between the regions. 
8 For a discussion of the equivalence of production and income taxes within the context of this model, see McLure [15].

${ }^{9}$ More specifically, for each of the independent variables, a uniform distribution between the ranges was chosen for simulation purposes. While the results presented here are based upon 512 observations, these results did not differ markedly from those obtained from 256 observations.

10 The existence of an index number problem in the choice of weights for these price effects should be noted here. For the purposes of this study, post-tax values of $\mathrm{X}$ were used as weights for analysis on the uses side of income. Since New York production declined because of the tax, this choice of weights will produce a smaller effect on the uses side of income in both regions than would have been the case if pre-tax weights had been chosen. Further, the decrease in real income resulting from the decrease in the production of New York $\left(\mathrm{P}_{\mathrm{X}} \bullet \partial \mathrm{X}\right)$ is ignored in this analysis, since this can be seen as being at least partially offset by increased production in the remainder of the U.S.

\section{REFERENCES}

[1] Aaron, Henry. "A New View of Property Tax Incidence," American Economic Review, 64 (May 1974), pp. 212-221.

[2] Brown, H. The Economics of Taxation. New York: Holt and Company, 1924

[3] Brownlee, O. Estimated Distribution of Minnesota Taxes and Public Expenditures Benefits. Minneapolis: University of Minnesota Press, 1960.

[4] Bruno, S. "Corporate Income Tax, Oligopolistic Markets and Immediate Tax Shifting," Public Finance, Vol. 25, No. 3 (1970), pp. 127-142.

[5] Burkhead, Jesse. "Public Finance as an Integral Part of Regional Accounts" in Elements of Regional Accounts, Werner Hirsch (ed.). Baltimore: Johns Hopkins Press, 1964, pp. 51-77.

[6] Glickman, Norman J. "An Econometric Forecasting Model for the Philadelphia Region," Journal of Regional Science, 11(1971), pp. $15-32$

[7] Green, R. J. A Long Range Econometric Forecasting Model for Illinois. University of Illinois, Bureau of Economic and Business Research, 1967.

[8] Harberger, A. "The Incidence of the Corporation Income Tax," Journal of Political Economy (April 1967), pp. 135-147.

[9] Hirsch, Werner Z. "Input-Output Techniques for Urban Government Decisions," American Economic Review, 58 (May 1968), pp. 162-170.

[10] Houthakker, H., and L. Taylor. Consumer Demand in the U.S.: 1929-1970. Cambridge: Harvard University Press, 1966.

[11] Klein, Lawrence R. "The Specification of Regional Econometric Models," Papers of the Regional Science Association, 23 (1969), pp. 105-115.

[12] Lichtenberg, R. M. One-Tenth of a $\mathrm{Na}$ tion. Cambridge: Harvard University Press, 1960.

[13] Marshall, A. Principles of Economics. Eighth edition. London: MacMillan and Company, 1890.

[14] "Reply to the Questionnaire of the Royal Commission on Local Taxation," quoted by C. Bickerdike, "Taxation of Site
Values," Economic Journal, 12 (1897), pp. 472-484.

[15] McLure, C. "The Inter-Regional Incidence of General Regional Taxes," Public Finance, 24 (1969), pp. 457-483.

[16] . "The Interstate Exporting of State and Local Taxes: Estimates for 1962," National Tax Journal (March 1967), pp. 49-77.

[17] Mieszkowski, P. "On the Theory of Tax Incidence," Journal of Political Economy, 75 (June 1967), pp. 250-262.

[18] _Tax Incidence Theory: The Effects of Taxes on the Distribution of Income," Journal of Economic Literature, 7 (December 1969), pp. 1103-1124.

[19] _ "The Property Tax: An Excise Tax or a Profits Tax?" Journal of Public Economics, 1 (1972), pp. 73-96.

[20] Murgrave, Richard. "Is the Property Tax on Housing Regressive," American Economic Review, 64 (May 1974), pp. 222-229.

[21] The Theory of Public Finance. New York: McGraw-Hill Book Company, 1959.

[22] Musgrave, R., and D. Daicoff. "Who Pays Michigan Taxes?" Michigan Tax Study Staff Papers, Harvey Brazer (ed.). Lansing: Office of the Secretary of Finance, 1958

[23] Netzer, Dick. "Data for the Public Finance Sub-Account," in Elements of Regional Accounts, Werner Hirsch (ed.). Baltimore: Johns Hopkins Press, 1964, pp. 87-100.

[24] _. "The Incidence of the Property Tax Revisited," National Tax Journal (December 1973), pp. 515-535.

[25] Perloff, H., and C. Levin. "Toward an tegrated System of Regional Accounts: Stocks, Flows and the Analysis of the Public Sector" in Elements of Regional Accounts, Werner Hirsch (ed.). Baltimore: Johns Hopkins Press, 1964, pp. 175-210.

[26] Phares, D. State-Local Tax Equity. Lexington: D. C. Heath and Company, 1973.

[27] Solow, R. "Capital, Labor and Income in Manufacturing" in The Behavior of Income Shares. Princeton: National Bureau of Economic Research, 1964, pp. 101-128. 